\title{
GRK-2 inhibitor lek kandidat u terapiji
} srčane insuficijencije

\author{
Marko Vasić, Nina Japundžić Žigon \\ Institut za kliničku farmakologiju, farmakologiju i toksikologiju, Medicinski fakultet, Univerzitet u Beogradu
}

Sažetak

\begin{abstract}
Pored značajnog napretka farmakoterapije, srčana insuficijencija i dalje ostaje jedan od vodećih uzroka smrti u svetu. Postojeća terapija produžava život, ali ne dovodi do regresije patoloških promena u miokardu, već samo usporava njihovu progresiju. Ključnu ulogu u nastanku srčane insuficijencije ima disfunkcija beta adrenergičkih receptora ( $\beta A R)$, kao i povećanje aktivnosti kinaze vezane za G-protein tip 2 (GRK-2). Novi kanditat za lek u srčanoj insuficijenciji je inhibitor $G$ protein kinaze tip 2 (ßARKct) koji sprečava nishodnu regulaciju, odnosno desenzitizaciju $\beta A R$ u srčanoj insuficijenciji. Eksperimentalni nalazi pružaju dokaze da $\beta A R K c t$ zaustavlja začarani krug propadanja mišića i obnavlja snagu srčane kontakcije, kao i da vrši reverziju patoloških promena u insuficijentnom miokardu. $U$ radu su prikazana najnovija saznanja o ulozi $\beta A R$ i njihove desenzitizacije u srčanoj insuficijenciji, mehanizam dejstva $\beta$ ARKct i ohrabrujući nalazi eksperimentalnih i translacionih kliničkih studija.
\end{abstract}

Ključne reči

\section{Uvod}

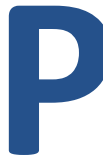

ored značajnog napretka farmakoterapije poslednjih decenija dvadesetog i dvadest prvog veka, srčana insuficijencija i dalje ostaje jedan od vodećih uzroka smrti u svetu ${ }^{1}$. Uvođenjem efikasnih diuretika, lekova koji modifikuju rad renin-angiotenzin aldosteronskog sistema (ACEI, sartani) i vazodilatatornih beta-blokatora, značajno se produžio vek bolesnika i poboljšao kvalitet života. Međutim, postojeća terapija ne dovodi do regresije nastalih patoloških promena u miokardu, već samo usporava njihovu progresiju.

Ključnu ulogu u nastanku hronične srčane insuficijencije ima disfunkcija beta adrenergičkih receptora (BAR). Poznato je da remodelovanje regulacionih mehanizama u srčanoj insuficijenciji izlaže srce povećanoj koncentraciji kateholamina koji na srce deluju preko $\beta A R$. U početku bolesti srce se brani smanjivanjem broja $\beta A R$ u membrani kardiomiocita nishodnom regulacijom receptora. Međutim, ovo smanjenje broja $\beta A R$ kasnije doprinosi zatvarnju začaranog kruga i rapidnom smanjenju kontraktilne snage srca.

Nov kanditat za lek u srčanoj insuficijenciji je inhibitor $G$ protein kinaze tip 2 ( $\beta A R K c t)$ koji sprečava nishodnu regulaciju $\beta A R$, zaustavlja začarani krug propadanja mišića i povećava snagu srčane kontakcije. Na osnovu brojnih eksperimentalnih nalaza može se zaključiti da BARKct ne samo da poboljšava funkciju miokarda već vrši i reverziju patoloških promena. $U$ daljem tekstu prikazan je mehanizma dejstva $\beta A R K c t$ i glavni nalazi ekperimentalnih i translacionih studija.

\section{Signalni put $\beta$ adrenergičkih receptora $u$ zdravom srcu i intracelularni mehanizmi kontrole}

$\beta A R$ je klasični transmembranski receptor sa 7 transmembranskih domena, ekstracelularnim amino terminalnim krajem i intracelularnim karboksilnim repom. Nakon vezivanja prirodnog liganda za $\beta A R$, adrenalina, noradrenalina, dopamina ili, pak, beta adrenergičkih agonista, dobutamina, dolazi do aktivacije $\mathrm{G}$ proteina. $G$ protein je intarcelularni heterotrimer koji se satoji od tri subjedinice $\alpha, \beta, \gamma$. $\alpha$ subjedinica se odmah disosuje od druge dve subjedinice i aktivira adenilat ciklazu prouzrokujući sintezu cikličnog adenozin-monofosfata (cAMP) i aktivaciju protein kinaze A (PKA). PKA fosforiliše struktruni membranski protein fosfolamban i na taj način sprečava inhibiciju kalcijum ATP-aze i omogućava izbacivanje kalcijuma iz sarkoplazmatskog retikuluma tokom srčane kontrakcije. Porast intracelularnog kalcijuma dovodi do snažne kontrakcije srca jer angažuje veći broj aktinskih i miozinskih vlakana.

$U$ fiziološkim uslovima, uporedo sa aktivacijom $\beta A R$, pokreće se kontrolni intracelularni mehanizam desenzitizacije koji ograničava njihovu funkciju (slika 1). Desenzitizaciju $\beta A R$ pokreće vezivanje GRK-2 za $\beta \gamma$ subjedinicu G proteina $(G \beta \gamma)$. GRK-2 pripada porodici citosolnih serin/treonin kinaza koje postoje u 7 izoenzimskih formi u organizmu. U ćelijama miokarda najviše je eksprimirana kinaza 2. Vezivanjem GRK-2 za G $\beta$ Y subjedinicu dolazi do njegove translokacije u membranu kardiomiocita odakle GRK-2 može da fosforiliše $\beta A R$. 


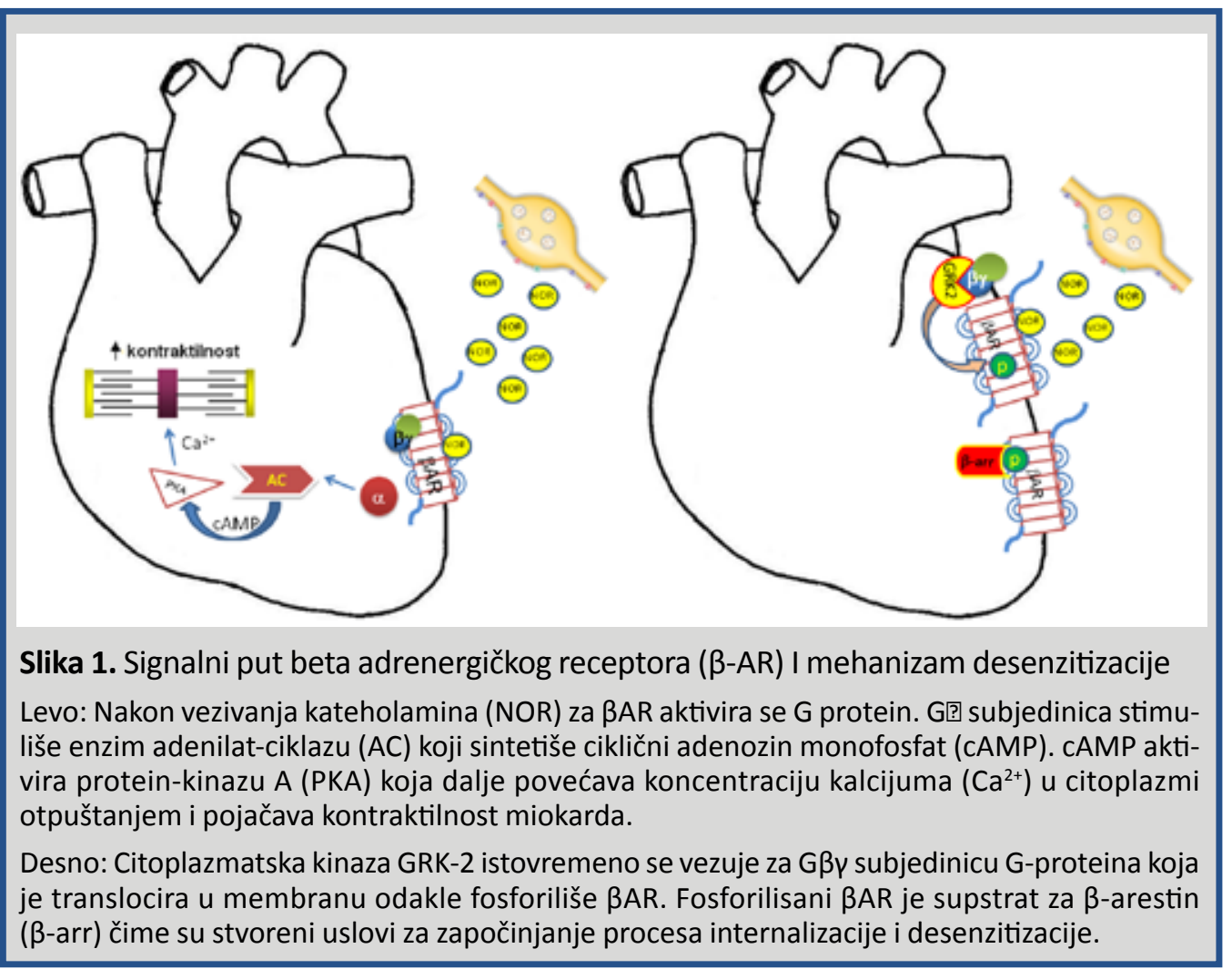

Fosforilacija menja konformaciju $\beta A R$ i omogućava vezivanje $\beta$ arestina, citoplazmatskog proteina. $\beta$ arestin uz pomoć drugih proteina citoplazme, klatrina i adaptina, invaginira membranu oko $\beta A R$ formirajući intracelularnu vezikulu. Odvajanje vezikule od membrane ostvaruje se preko GTP vezujućeg proteina dinamina (slika 2). Sudbina internalizovanog receptora može biti dvojaka. Receptor može biti brzo ponovo vraćen u membranu, tj. Recikliran, ili može podleći razgradnji fuzijom sa lizozomalnom vezikulom. Ukoliko receptori formiraju međusobno heterodimere, njihova sudbina nakon internalizacije se može menjati.

\section{Beta adrenergički receptori u insuficijentnom srcu}

U miokardu postoje 3 tipa $\beta A R: \beta A R_{1} \beta A R_{2}$ i $\beta A R_{3}$ koji su u fiziološkim uslovima eksprimirani u odnosu $80: 18$ : 2. Očuvana funkcija $\beta A R_{1}$ je najvažnija za medijaciju pozitivno inotropnog dejstva kateholamina. $U$ srčanoj insuficijenciji odnos $\beta A R_{1}: \beta A R_{2}$ je promenjen na $50: 50$ što doprinosi i pokretanju pro-apototskih mehanizama od strane $\beta A R_{1}\left(\beta A R_{2}\right.$ receptori su povezani sa $G$ inhibitornim proteinom i smatra se da deluju protektivno na kardiomiocite, $\left.{ }^{2-4}\right)$. Pored toga, zbog hiperadrenergičkog

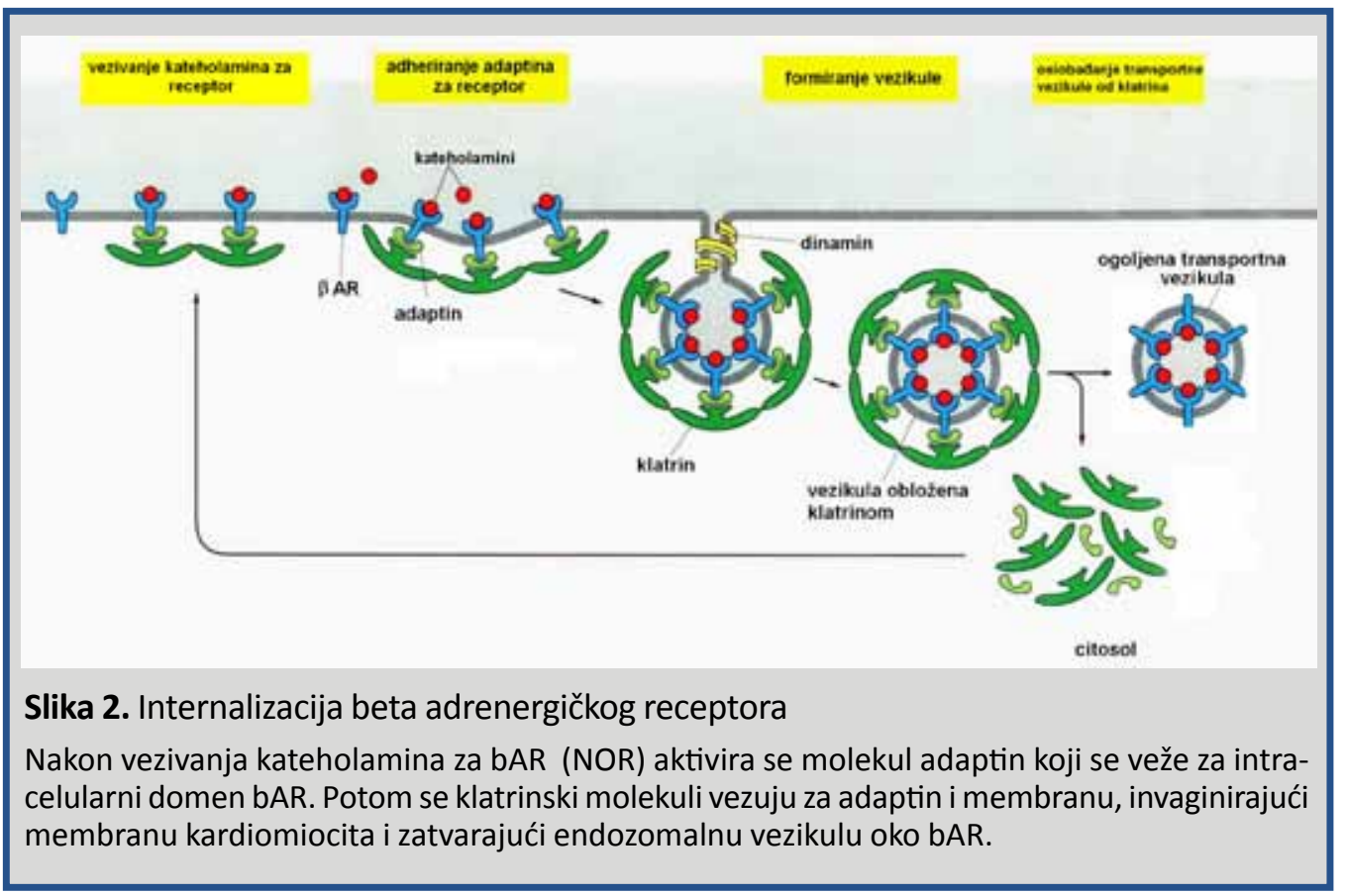


statusa u srčanoj insuficijenciji i povećane stimulacije $\beta A R_{1}$ od strane noradrenalina i adrenalina ${ }^{5-8}$, dolazi do kompenzatornog povećanja ekspresije GRK-2 već u ranim fazama oboljenja ${ }^{9-13}$. GRK-2 pokreće intenzivan proces desenzitizacije $\beta A R_{1}{ }^{9,14,15,10,16}$ i predstavlja rani odbrambeni mehanizma srca, te je predložen kao novi biomarker srčane insuficijencije ${ }^{17-19}$. Međutim, u hroničnim uslovima usled internalizacije i smanjenja broja $\beta A R_{1}$ na površini kardiomiocita slabi kontraktilna funkcija srca i dolazi do razvoja začaranog kruga i ubrzanog propadanja srčanog mišića 6 .

\section{Mehanizam dejstva $\beta A R K c t$ i potvrda efi- kasnosti u eksperimentalnim modelima srčane insuficijencije}

GRK-2 inhibitor (BARKct) je deo peptida GRK-2, tačnije karboksilni deo peptidnog lanca. Njegov mehanizam dejstva zasniva se na kompetitivnom vezivanju za $\beta$ Y subjedinicu G proteina i istiskivanju GRK-2 iz membrane kardiomiocita.

$\mathrm{U}$ dva genetska eksperimentalna modela srčane insuficijencije knock out (KO) tehnologijom kod miševa pokazan je značaj GRK-2 u nastanku srčane insuficijencije. Jedan genetski model srčane insuficijencije dobijen je delecijom gena za mišićni LIM domen protein - MLP ${ }^{20}$. Drugi genetski model srčane insuficijencije je dobijen izazivanjem hiperekspresije kalcijum vezujućeg proteina kalsekvestrina $\mathrm{CSO}^{21}$. $U$ oba genetska modela srčane insuficijencije koadministracija $\beta A R K c t$ ne samo da je sprečila razvoj srčane insuficijencije već je dovela i do regresije promena, kao i do značajnog produžetka životnog veka ovih transgenih miševa. Takođe je pokazano da koadministracija beta-blokatora i ßARKct ima sinergističko, povoljno dejstvo u ovom eksperimentalnom modelu srčane insuficijencije ${ }^{21}$.

Eksperimenti na GRK-2 KO miševima pokazli su da je GRK-2 neophodan za organogenezu srca. Delecija GRK-2 gena dovela je do smrti embriona miševa ${ }^{22}$. Međutim, kod heterozigotnih GRK-2 KO miševa koji imaju ekspresiju 50 \% GRK-2 gena, kao i kod miševa transfeciranih sa $\beta A R K c t$ došlo je do pojačanja kontraktilne snage srca $i$ povećanja kontraktilne rezerve $\beta A R^{23}$. Kod miševa kod kojih je izveden knock-down GRK-2 gena, a koji su potom podvrgnuti ligaturi prednje koronarne arterije (eksperimentalni model miokardne nekroze) došlo je do prevencije smrtnog ishoda, reverzije patoloških promena u levoj komori i povećanja kontraktilne funkcije mio$\operatorname{karda}^{24}$. U istoj studiji pokazano je da je delecija GRK-2 gena efikasnija od farmakološke blokade $\beta A R$.

\section{Translacija eksperimentalnih podataka na čoveka}

Translacija podrazumeva prvu primenu eksperimentalnih nalaza kod čoveka. Translacione studije pripadaju nultoj fazi kliničkih ispitivanja. Postoje dva pristupa u translaciji $\beta$ ARKct. Prvi pristup je pokušaj primene $\beta A R K c t$ putem genske terapije, transferom gena $\beta A R K c t$ uz pomoć adenovektora ili adenoasociranih vektora (slika 3) i drugi, klasični put, razvojem lekova selektivnih GRK-2 inhibitora.

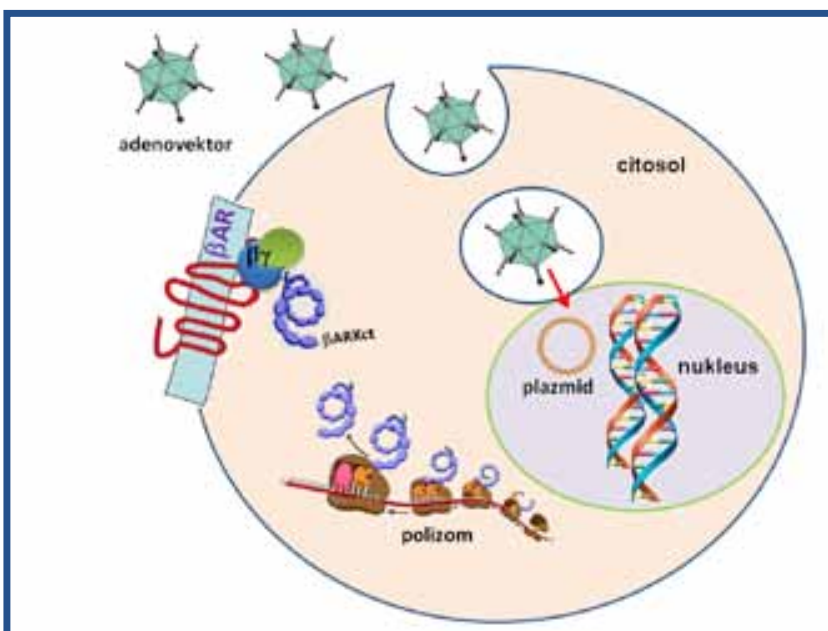

Slika 3. Transfekcija miokardiocita sa adenovirusnim vektorom

Adenovirusni vektor procesom endocitoze inficira kardiomiocit, oslobađa plazmid u jedro i započinje transkripciju i translaciju bARKct.

Vektori su modifikovani adenovirusi ili adenoasocirani virusi kojima je oduzeta sposobnost replikacije i čiji je genom modifikovan tako što je umesto gena za virusni proteinski omotač ubačen je gen za $\beta A R K c t$. Transfekcija sa $\beta A R K c t$ u kardiomiocite adenovektorima pokazala se efikasnom u in vitro uslovima i u in vivo animalnim modelima srčane insuficijencije. $\beta A R K c t$ dodat kulturi zečijih i humanih kardiomiocita potencira signalizaciju $\beta A R^{25-27}$. In vivo, $\beta A R K c t$ je primenjen intrakardijalnom inokulacijom adenovirusa kod zečeva kod kojih je miokardna funkcija oštećena ligaturom prednje descendentne grane leve koronarne arterije ${ }^{28,29}$. $\beta$ ARKct je smanjio proces patološkog remodelovanja leve komore, očuvao kontraktilnost leve komore i funkciju adrenergičkih beta-receptora. Transfekcija srca adenovirusima može se raditi direktnom intrakardijalnom injekcijom, intravenski ili kroz koronarne arterije životinja. Dva protokola genske terapije na ljudima u 2008. godini ${ }^{30} \mathrm{i} 2009$. godi$\mathrm{ni}^{31}$ pokazuju da ljudi dobro podnose transfekcije sa adenovektorima i adenoasociranim vektorima u toku koronarografije.

Grupa istraživača iz SAD, iz Mičigena, Njujorka i Pensilvanije ${ }^{32}$, identifikovala je paroksetin $\left(\mathrm{Paxy}^{\circledR}{ }^{\circledR}\right.$, registrovan antidepresiv iz grupe selektivnih serotononskih inhibitora - SSRI) kao potentni direktni inhibitor GRK-2. U in vitro i in vivo eksperimentalnim modelima pokazali su da paroksetin pojačava snagu srčane kontrakcije, što je prihvaćeno od strane Food and Drug Administracije. Paroksetin je registrovan u SAD od 1992. godine. U okviru postmarketinških studija nije zabeležena kardiotoksičnost paroksetina, ali je bilo prijava rođenja dece sa razvojnim kardiovaskularnim defektima od majki koje su tretirane paroksetinom za vreme trudnoće. Ovaj teratogeni efekat mogao bi imati veze sa inhibicijom GRK-2 i nalazima kod KO GRK-2 miševa. Važno je napomenuti da su plazma koncentracije paroksetina za postizanje antidepresivnog efekta niže za 1-2 log skale od koncentracija koje postižu maksimalnu inhibiciju GRK-2 u srcu. Interesantno je napomenuti da fluoksetin, srodan lek iz 
grupe SSRI, ne poseduje sposobnost inhibicije GRK-2. Svakako bi bilo važno uporediti ishod srčane insuficijencije kod depresivnih bolesnika na hroničnoj terapiji sa paroksetinom i bolesnika na hroničnoj terapiji sa fluoksetinom. To bi možda otvorilo mogućnost uvođenja nove indikacije za paroksetin u okviru IV faze kliničkih ispitivanja.

\section{Literatura}

1. McMurray J et al. ESC Guidelines for the diagnosis and treatment of acute and chronic heart failure 2012. Eur J Heart Fail 2012 (8):803-69.

2. Communal C, Singh K, Sawyer DB, Colucci WS. Opposing effects of $\beta 1$ - and $\beta 2$ - adrenergic receptors on cardiac myocyte apoptosis: role of a pertussis toxinsensitive $G$ protein. Circulation 1999;100:2210-2.

3. Chesley A, Lundberg MS, Asai T, Xiao RP, Ohtani S, Lakatta EG, et al. The $\beta 2$-adrenergic receptor delivers an antiapoptotic signal to cardiac myocytes through $\mathrm{Gi}$-dependent coupling to phosphatidylinositol 3-kinase. Cir Res 2000;87:1172-9.

4. Zhu WZ, Zheng M, Koch WJ, Lefkowitz RJ, Kobilka BK, Xiao RP. Dual modulation of cell survival and cell death by â2-adrenergic signalling in adult mouse cardiomyocytes. Proc Natl Acad Sci USA 2001;98:1607-12.

5. Rockman HA, Koch WJ, Lefkowitz RJ. Seven-transmembranespanning receptors and heart function. Nature 2002;415:206-12.

6. Lymperopoulos A, Rengo G, Koch WJ. Adrenal adrenoceptors in heart failure: finetuning cardiac stimulation. Trends Mol Med 2007;13:503-11.

7. Packer M. The development of positive inotropic agents for chronic heart failure: how have we gone astray? J Am Coll Cardiol 1993;22:119A-26A.

8. Bristow MR. $\beta$-adrenergic receptor blockade in chronic heart failure. Circulation 2000;101:558-69.

9. Petrofski JP, Koch WJ. The $\beta$-adrenergic receptor kinase ( $\beta A R K 1)$ in heart failure. J Moll Cell Cardiol 2003;35:1167-74.

10. Harris CA, Chuang TT, Scorer CA. Expression of GRK2 is increased in the left ventricles of cardiomyopathic hamsters. Basic Res Cardiol 2001;96:364-8.

11. Yi XP, Gerdes AM, Li F. Myocyte redistribution of GRK2 and GRK5 in hypertensive, heart-failure-prone rats. Hypertension 2002;39:1058-63.

12. Ungerer M, Böhm M, Elce JS, Erdmann E, Lohse MJ. Altered expression of $\beta$-adrenergic receptor kinase and $\beta$ 1-adrenergic receptors in the failing human heart. Circulation 1993;87:454-63.

13. Dzimiri N, Muiya P, Andres E, Al-Halees Z. Differential functional expression of human myocardial $G$ protein receptor kinases in left ventricular cardiac diseases. Eur J Pharmacol 2004;489:167-77.

14. Brodde OE. Beta-adrenoceptors in cardiac disease. Pharmacol Ther 1993;60:405-30.

15. Bristow MR, Ginsburg R, Umans V, Fowler M, Minobe W, Rasmussen $R$, et al. $\beta 1$-and $\beta 2$-adrenergic-receptor subpopulations in nonfailing and failing human ventricular myocardium: coupling of both receptor subtypes to muscle contraction and selective $\beta 1$ receptor down-regulation in heart failure. Circ Res 1986;59: 297-309.

16. Harris CA, Chuang TT, Scorer CA. Expression of GRK2 is increased in the left ventricles of cardiomyopathic hamsters. Basic Res Cardiol 2001;96:364-8.
17. Iaccarino G, Barbato E, Cipolletta E, De Amicis V, Margulies KB, Leosco D, et al. Elevated myocardial and lymphocyte GRK2 expression and activity in human heart failure. Eur Heart J 2005;26:1752-8.

18. Hata JA, Williams ML, Schroder JN, Lima B, Keys JR, Blaxall BC, et al. Lymphocyte levels of GRK2 ( $\beta A R K 1)$ mirror changes in the LVAD-supported failing human heart: lower GRK2 associated with improved $\beta$-adrenergic signaling after mechanical unloading. J Card Fail 2006;12:360-8.

19. Bonita RE, Raake PW, Otis NJ, Chuprun JK, Spivack T, Dasgupta A, et al. Dynamic changes in lymphocyte GRK2 levels in cardiac transplant patients: a biomarker for left ventricular function. Clin Transl Sci 2010;3:14-8.

20. Rockman HA, Chien KR, Choi DJ, laccarino G, Hunter JJ, Ross Jr J, et al. Expression of a $\beta$-adrenergic receptor kinase 1 inhibitor prevents the development of myocardial failure in gene-targeted mice. Proc Natl Acad Sci USA 1998;95: 7000-5.

21. Harding VB, Jones LR, Lefkowitz RJ, Koch WJ, Rockman HA. Cardiac $\beta$ ARK1 $b$ inhibition prolongs survival and augments $\beta$ blocker therapy in a mouse model of severe heart failure. Proc Natl Acad Sci USA 2001;98:5809-14.

22. Jaber M, Koch WJ, Rockman H, Smith B, Bond RA, Sulik KK, et al. Essential role of ?- $\mathrm{C} 1$ in cardiac development and function. Proc Natl Acad Sci USA 1996;93:12974-9.

23. Rockman HA, Choi DJ, Akhter SA, Jaber M, Giros B, Lefkowitz RJ, et al. Control of myocardial contractile function by the level of $\beta$-adrenergic receptor kinase 1 in gene-targeted mice. J Biol Chem 1998;273:18180-4

24. Raake PW, Vinge LE, Gao E, Boucher M, Rengo G, Chen X, et al. $G$ protein-coupled receptor kinase 2 ablation in cardiac myocytes before or after myocardial infarction prevents heart failure. Circ Res 2008;103:413-22.

25. Drazner MH, Peppel KC, Dyer S, Grant AO, Koch WJ, Lefkowitz RJ. Potentiation of $\beta$-adrenergic signaling by adenoviral-mediated gene transfer in adult rabbit ventricular myocytes. J Clin Invest 1997;99:288-96.

26. Akhter SA, Skaer CA, Kypson AP, McDonald PH, Peppel KC, Glower DD, et al. Restoration of $\beta$-adrenergic signaling in failing cardiac ventricular myocytes via adenoviral-mediated gene transfer. Proc Natl Acad Sci USA 1997; 94:12100-5.

27. Williams ML, Hata JA, Schroder J, Rampersaud E, Petrofski J, Jakoi $A$, et al. Targeted $\beta$-adrenergic receptor kinase (BARK1) inhibition by gene transfer in failing human hearts. Circulation 2004;109:1590-3.

28. White DC, Hata JA, Shah AS, Glower DD, Lefkowitz RJ, Koch WJ. Preservation of myocardial $\beta$-adrenergic receptor signaling delays the development of heart failure after myocardial infarction. Proc Natl Acad Sci USA 2000;97:5428-33.

29. Shah AS, White DC, Emani S, Kypson AP, Lilly RE, Wilson K, et al. In vivo ventricular gene delivery of a $\beta$-adrenergic receptor kinase inhibitor to the failing heart reverses cardiac dysfunction. Circulation 2001;103:1311-6

30. Hajjar RJ, Zsebo K, Deckelbaum L, Thompson C, Rudy J, Yaroshinsky $A$, et al. Design of a phase $1 / 2$ trial of intracoronary administration of AVV1/SERCA2a in patients with heart failure. J Card Fail 2008;14:355-67.

31. Jaski BE, Jessup ML, Mancini DM, Cappola TP, Pauly DF, Greenberg B, et al. Calcium upregulation by percutaneous administration of gene therapy in cardiac disease (CUPID Trial), a firstin-human phase 1/2 clinical trial. J Card Fail 2009;15: 171-81.

32. Thal DM et al. Paroxetine is a direct inhibitor of g protein-coupled receptor kinase 2 and increases myocardial contractility. ACS Chem Biol 2012;7(11):1830-9. 
Abstract

In spite of significant advancement in pharmacotherapy, heart failure remains one of the main causes of death worldwide. The existing treatment of heart failure prolongs the live span by slowing down the pathological process but do not induce their regression and heart healing. The beta adrenergic receptor dysfunction represents a hallmark abnormality of chronic heart failure, and increased G-protein-coupled receptor kinase 2 (GRK-2) levels in failing myocardium occurs in early stages of disease. A new drug candidate for heart failure is an inhibitor of G-protein-coupled receptor kinase 2 (BARKct) that prevents BAR down-regulation and desensitization that occur in early stages of the failing heart. Experimental data are encouraging, and provide evidence that BARKct prevents the heart from failing and recovers its function. This paper summarizes up-to-date knowledge on BAR signaling and desenzitisation in heart failure, mechanism of action of BARKct and the promising findings from experimental and translational clinical studies. 